\title{
THE CHANGE OF VOLUME IN CLARK AND CAD- MIUM CELLS AND ITS RELATION TO CHANGE OF ELECTROMOTIVE FORCE DUE TO PRESSURE.
}

By Rolla R. Ramsey.

W

HEN a Clark or Cadmium cell is put under pressure its E.M.F. is increased, as I have shown in a previous paper. ${ }^{1}$ Since if the current is sent backwards through the cell a greater amount of energy is required to maintain the current constant in the case when pressure is applied, than that required when the cell is not under pressure, one would be led to expect that the volume of the cell was increased or that energy was used up in overcoming pressure.

Gilbault ${ }^{2}$ has calculated this change in certain cells by means of a large number of measurements of densities of different per cent. solutions of the salt contained in the cell. It seemed to me to be interesting to measure the actual change and to compare this value with the value obtained by theoretical calculation.

Theoretical.--Suppose a cell whose E.M.F. is $E$, at zero pressure to be placed under a pressure, $P$ say, and the E.M.F. be found to be increased by an amount, $e$. If in the first place a current $i$ is allowed to pass through the cell the energy developed is

or

$$
\text { Eit, }
$$

$$
E Q \text {. }
$$

where $Q$ is the quantity of electricity.

The same amount of energy would be used up in overcoming the E.M.F. of the cell if the same quantity of electricity were forced backwards through the cell. Place the cell under pressure

1 Phys. Rev., Vol. I3, p. I, I9or.

${ }^{2}$ Lum. El., Vol. 42, pp. 7, 63, 175, 220, 1891. 
and force the same quantity backwards through the cell and the energy used in overcoming the E.M.F. of the cell is,

or

$$
(E+e) Q,
$$

$$
E Q+e Q \text {. }
$$

Since the first term is the energy required to overcome the ordinary E.M.F. of the cell, the second is the extra required due to the fact that the cell is under pressure, or the amount used up in external work in overcoming pressure (unless the nature of the electrolyte is changed by the pressure). This would require a change in volume. The external work in overcoming pressure would be,

$$
\text { Pdv. }
$$

This quantity should equal the added quantity of energy

$$
P d v=e Q .
$$

It will be apparent that when $e$ is positive the volume of a cell will increase when current is forced backward through the cell of will decrease when allowed to flow in the usual manner.

Knowing $e, Q$, and $P$, $d v$ can be calculated.

For Clark cell :

Let $e=\mathrm{I} 1.6 \times \mathrm{IO}^{-6}$ volts or $\mathrm{I}, \mathrm{I} 60$ C.G.S. units, the increase of E.M.F. per atmosphere pressure.

$$
\begin{aligned}
Q & =\mathrm{I} \text { C.G.S. unit quantity. } \\
P & =\mathrm{I} \text { atmosphere, or } \mathrm{I}, 050,000 \text { dynes. } \\
d v & =\frac{e Q}{P} \\
& =\frac{\mathrm{I}, \mathrm{I} 60 \times \mathrm{I}}{\mathrm{I}, 050,000}=\begin{array}{c}
.00 \mathrm{I} \mathrm{I} \text { cu. cm. per C.G.S. unit quan- } \\
\text { tity, }
\end{array}
\end{aligned}
$$

or $d v=$. I I cu. millimeter per coulomb.

For cadmium cell :

$$
\begin{aligned}
e & =7.6 \times \mathrm{IO}^{-6} \text { volts. } \\
d v & =.072 \mathrm{cu} . \text { millimeters per coulomb. }
\end{aligned}
$$


Apparatus and Methods. - The method of measuring the change of volume was to observe by means of a cathetometer, the rise or fall of the liquid in a capillary tube which was attached to the cell. The cell was connected in series with four to seven gravity cells and an instrument for measuring current. The cell was made of glass tubing in the $\mathbf{H}$ form, Fig. I. The $\mathbf{H}$ was blown and the electrodes placed as directed, in the case of the Clark cell, by Kahle ; ${ }^{1}$ in the case of the cadmium cell by Jaeger and Wachsmuth. ${ }^{2}$ To one stem of the $\mathbf{H}$ a stop-cock was fused to the other a capillary stem of known cross-section. (In later cells the stem was heated and drawn to a capillary and the diameter measured afterwards by cutting the tube in two and placing under a micrometer microscope.) The cell was now filled through the stop-cock with the saturated electrolyte. By means of the stop-cock the electrolyte could be kept at any desired height in the tube. The cathetometer was one made by the Société Genevoise reading to $\frac{1}{b}$ millimeter. For current measurement a tangent galvanometer was used at first. In the later observations a Weston mil-ammeter was found

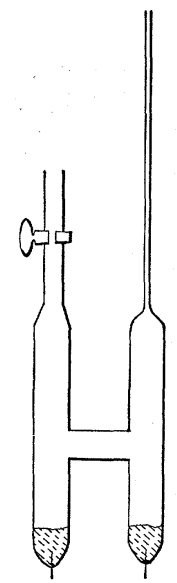

Fig. 1. to answer all requirements. Several forms of voltameters and electrolytic ammeters were tried but were found to be useless for the work.

The apparatus was set up in a basement room. A thermostat was not attempted. To avoid rapid changes of temperature the cell was immersed in a bath of coal oil, which was immersed in a six-gallon jar of water. The jar was placed in a wooden box and packed with excelsior. By this means the temperature changes were not rapid, but there were variations of a degree or more from day to day. Attempts were made at first to run the current through the cell several days at a time and thus to get a large change in volume. This failed for two reasons. After the current had been running for some time, from a half hour to three hours, depending upon the size of the electrodes, the cell would polarize, 
rendering the current intermittent, making the readings of the ammeter uncertain. Electrolytic ammeters were substituted, but the observations were uncertain on account of the temperature variations. Even after the coefficient was known the largest calculated change of volume fell within the limits of errors of the temperature coefficient. In one case the cell was packed in ice but the index gradually rose in the tube. This change was comparable to the change due to the current (the current strength being very small after polarization of the cell). The probable cause of this apparent change of volume was the aging of the glass of which the cell was composed. The best results were found to be obtained by short runs with the temperature as nearly constant as possible. Since the changes of volume were small and the temperature variable, the accuracy was not as great as was hoped to be obtained.

The readings were taken in the following order: The reading of the cathetometer was noted, the current started and readings taken at stated intervals, every minute or two. As soon as the ammeter began to show fluctuations the current was broken and the height of the index again noted by means of the cathetometer.

TABLE I.

July 26. Cell No. IV.

\begin{tabular}{c|c|c|c}
\hline Time. & Temp. & Height. & Current in Milliamperes. \\
\cline { 3 - 4 } 5.42 p. m. & $0^{\circ}$ & 35.344 & 1.5 \\
44 & & & 1.53 \\
46 & & 35.260 & 1.48 \\
47 & & 35.240 & 1.4 \\
48 & & & \\
49 & & & 1.39 \\
50 & & 35.180 & 1.37 \\
52 & & & 1.32 \\
55 & & 35.100 & 1.2 \\
58 & & $d v=.254 \mathrm{cu}$. & millimeter. $Q=1.48$ coulombs. \\
59 & &
\end{tabular}

Table I. contains a set of readings which will serve as as ample. The quantity of electricity was obtained from the area of a curve plotted with time as abscissas and current as ordinates. The current always 
fell on one half or less of its initial value before the polarization fluctuations set in. These fluctuations were quite erratic. At times the galvanometer would drop to zero for an instant, even with seven cells on. In one case a large number of cells were connected on and the volume change became erratic. Hydrogen bubbles were found in the cell afterwards. The probable cause of the polarization is the small solubility of the depolarizer, mercurous sulphate. The solubility of mercurous sulphate being, according to Dolezalek, ${ }^{1} .05$ per cent. The E.M.F. of the cell as shown by means of a potentiometer was lowered when polarized. In the case of a Clark cell I.4I 7 volts at one time. After standing a few hours the cell regained its initial E.M.F. In one case after a continuous run of a week, upon resting 24 hours a hasty comparison showed the E.M.F. to be 1.425 volts at $24.4^{\circ}$ temperature. The E.M.F. should be I.42 I volts, assuming Jaeger's ${ }^{2}$ values. The comparison was made with a cadmium cell assuming Jaeger's values as found upon the same page.

Results. - Table II. contains a tabulated list of the various sets of observations upon Clark cells.

TABLE II.

Clark Cell.

\begin{tabular}{|c|c|c|c|c|c|}
\hline Date. & \multirow{2}{*}{$\frac{\text { Cell. }}{\text { I }}$} & \multirow{2}{*}{$\frac{\text { Temp. }}{16.0^{\circ}}$} & \multirow{3}{*}{$\begin{array}{c}\begin{array}{c}\text { Cross Section } \\
\text { in sq. mm. }\end{array} \\
1.11 \\
1.11\end{array}$} & \multirow{3}{*}{$\frac{d h .}{.1 \mathrm{~mm} .}$} & \multirow{2}{*}{$\frac{d v}{.111}$} \\
\hline Jan. 25 & & & & & \\
\hline April 21 & II & 19.6 & & & 1.72 \\
\hline 21 & II & 19.6 & 1.11 & 3.02 & 3.37 \\
\hline 22 & II & 19.6 & 1.11 & 1.2 & 1.34 \\
\hline May 31 & III & 21.7 & .368 & .76 & .276 \\
\hline June 3 & III & 22.6 & .368 & .40 & .147 \\
\hline 12 & III & 23.3 & .368 & .16 & .054 \\
\hline 13 & III & 23.8 & .368 & .42 & .154 \\
\hline 16 & III & 23.4 & .368 & .22 & .081 \\
\hline July 26 & IV & 0 & .104 & 2.44 & .254 \\
\hline 28 & IV & 0 & .106 & .16 & .017 \\
\hline 29 & IV & 0 & .107 & .46 & .049 \\
\hline Aug. 1 & IV & 0 & .111 & .24 & .026 \\
\hline 1 & IV & 0 & .111 & .88 & .097 \\
\hline
\end{tabular}

1 Jaeger, Die Normalelemente, p. Io.

2 Jaeger, Die Normalelemente, p. I 18. 
TABLE II.-Continued.

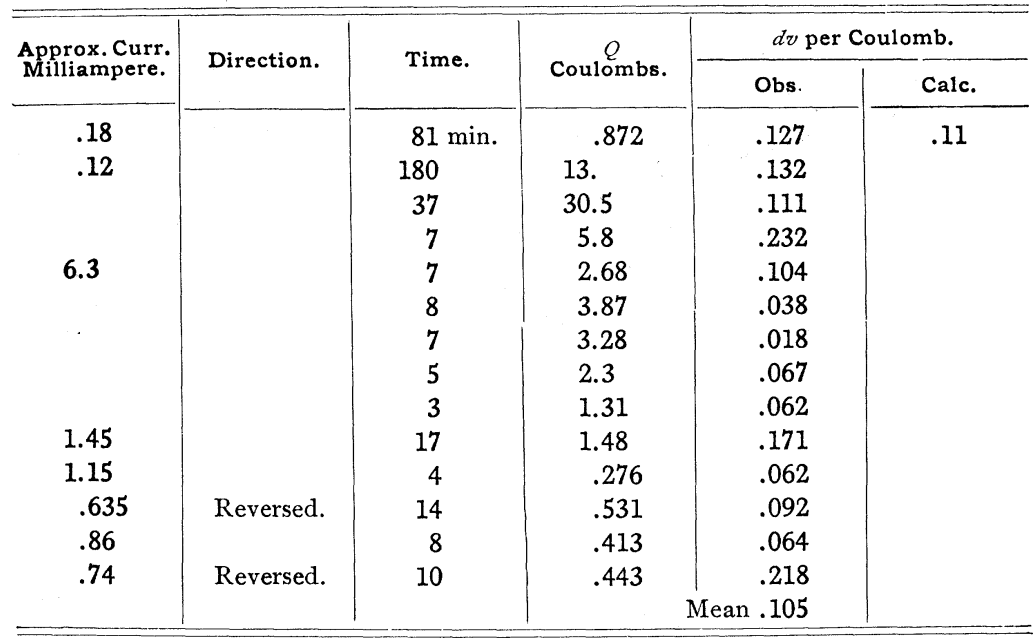

Table III. contains the work done on a cadmium cell. All the results on this cell fell below the calculated value. Judging from the general behavior of the cell I would say that this was probably due to a bubble of air in the cell. Owing to the crowded condition of the department it is necessary to tear down my apparatus, so I give my results as they now stand.

TABLE III.

Cadmium Cell.

\begin{tabular}{|c|c|c|c|c|c|}
\hline Date. & Cell. & Temp. & $\begin{array}{l}\text { Cross Section } \\
\text { sq. mm. }\end{array}$ & $d h$. & $d v$ \\
\hline Sept. 2 & $\mathrm{~V}$ & $22 .^{\circ} 6$ & .160 & $.8 \mathrm{~mm}$ & $.128 \mathrm{cu} . \mathrm{mm}$. \\
\hline Sept. 2 & $\mathrm{~V}$ & $22 .{ }^{\circ} 5$ & .160 & .14 & .022 \\
\hline Sept. 4 & $\mathrm{~V}$ & $22 .^{\circ}$ & .160 & .10 & .016 \\
\hline Sept. 5 & $\mathrm{~V}$ & $21 .^{\circ} 5$ & .160 & .5 & .080 \\
\hline \multirow{2}{*}{$\begin{array}{l}\text { Approx. Curr. } \\
\text { Milliampere. }\end{array}$} & \multirow{2}{*}{ Direction. } & \multirow{2}{*}{ Time. } & \multirow{2}{*}{$\underset{\text { Coulombs. }}{Q}$} & \multicolumn{2}{|c|}{$d v$ per Coulomb. } \\
\hline & & & & Obs. & Calc. \\
\hline 1.5 & & $30 \mathrm{~min}$. & 2.37 & .054 & .072 \\
\hline 1.9 & Reversed. & 5 & .57 & .039 & \\
\hline 1.7 & Reversed. & 3 & .31 & .052 & \\
\hline \multirow[t]{2}{*}{1.3} & & 20 & 1.64 & .048 & \\
\hline & & & \multicolumn{3}{|c|}{ Mean .048} \\
\hline
\end{tabular}


The observations marked " reversed" are taken with the current forced backwardt hrough the cell. The results from these observations are the same as those obtained when the current is flowing forward through the cell, showing that the effect is reversible.

Physical Laboratory, University of Missouri,

Columbia, Mo., Sept. I6, Ig02. 